\title{
Adsorption of soluble proteins to rumen bacteria and the role of adsorption in proteolysis
}

\author{
BY R. J. WALLACE \\ Rowett Research Institute, Bucksburn, Aberdeen AB2 9SB
}

(Received 18 June 1984 - Accepted 6 November 1984)

\begin{abstract}
1. Following the addition of ${ }^{14} \mathrm{C}$-labelled casein to mixed rumen bacteria at $39^{\circ}$, some radioactivity was adsorbed to the bacteria before the casein was hydrolysed. At $0^{\circ}$, the rate of hydrolysis was greatly diminished but adsorption still occurred, and this enabled a study of the adsorption mechanism to be made.

2. The adsorption of ${ }^{14} \mathrm{C}$-labelled casein to rumen bacteria was a saturable process. The maximum binding capacity was about $10 \mu \mathrm{g}{ }^{14} \mathrm{C}$-labelled casein $/ \mathrm{mg}$ bacterial protein.

3. The ability of bacteria to adsorb ${ }^{14} \mathrm{C}$-labelled casein was abolished when they had been boiled for $5 \mathrm{~min}$. Boiling caused the release of material from the bacteria which rendered some undigested protein soluble in $50 \mathrm{~g}$ trichloroacetic acid $/ 1$.

4. Adsorbed ${ }^{14} \mathrm{C}$-labelled casein could be partly displaced by the addition of Triton X100 or an excess of unlabelled casein, or by boiling, or by removal of capsular material by blending. Adsorbed ${ }^{14} \mathrm{C}$-labelled haemoglobin could similarly be displaced by an excess of cold casein.

5. When an excess of casein was added to bacteria to which glucose-6-phosphate dehydrogenase (EC I . I . I . 49) and glucosephosphate isomerase $(E C 5 \cdot 3.1 .9)$ had been adsorbed, little active enzyme was displaced.

6. The susceptibility of different ${ }^{14} \mathrm{C}$-labelled proteins to hydrolysis corresponded to their relative adsorption affinities.

7. The pattern of sensitivity to inhibitors of the adsorption mechanism was the same as that for the inhibition of the bacterial hydrolysis of ${ }^{14} \mathrm{C}$-labelled casein, and the synthetic substrates leucine $p$-nitroanilide and benzoyl arginine $p$-nitroanilide.

8. It was concluded that the adsorption site and the catalytic site for proteolysis by rumen bacteria are probably identical and so not likely to be subject to independent manipulation.
\end{abstract}

Several lines of research have indicated that the cell surface layers of rumen bacteria are of importance in the digestion of food protein in the rumen. When rumen bacteria are centrifuged, most of the proteolytic activity is sedimented and so is cell-associated (Blackburn \& Hobson, 1960; Wright, 1967; Nugent \& Mangan, 1981; Brock et al. 1982; Kopecny \& Wallace, 1982). Various disruption techniques have shown that the proteases occur in the outer layers of the bacteria, especially in material thought to be capsular in origin (Kopecny \& Wallace, 1982). Further evidence of the role of bacterial cell surfaces in proteolysis was obtained by Nugent \& Mangan (1981), who found that hydrolysis of lucerne (Medicago sativa) fraction I (18S) protein by rumen bacteria was preceded by its apparently irreversible adsorption to the bacteria.

If the adsorption of a substrate protein to bacterial surfaces is indeed a prerequisite for its hydrolysis, then this is clearly a site where protein degradation in the rumen could be manipulated. The experiments described in the present paper provide more information on the adsorption mechanism itself, and attempt to determine the role of adsorption as a part of the degradation process.

\section{METHODS}

\section{Preparation of a bacterial fraction from rumen fuid}

Three mature sheep fitted with rumen fistulas received twice daily a diet consisting of two parts hay and one part of a barley-based concentrate. Samples of rumen fluid were withdrawn using a sampling tube of diameter $13 \mathrm{~mm}$ and were immediately strained through 
four layers of muslin. Protozoa were then removed by centrifuging the fluid at $160 \mathrm{~g}$ for $10 \mathrm{~min}$ at $4^{\circ}$. This 'bacterial fraction' was used without further treatment, or was centrifuged once more $\left(27200 \mathrm{~g}, 15 \mathrm{~min}, 4^{\circ}\right)$ and resuspended in $30 \mathrm{~mm}$-potassium phosphate, $\mathrm{pH} 7 \cdot 5$, to the required cell concentration (resuspended rumen bacteria). In experiments where bacteria were subjected to shaking or blending, the procedures were the same as those used to extract proteases from rumen bacteria (Kopecny \& Wallace, 1982).

\section{Adsorption of proteins to rumen bacteria}

${ }^{14} \mathrm{C}$-Labelled proteins were prepared by reductive methylation using $\left[{ }^{14} \mathrm{C}\right]$ formaldehyde as described previously (Wallace, 1983), except that the specific radioactivity of the $\left[{ }^{14} \mathrm{C}\right]$ formaldehyde was increased to $0.5 \mathrm{Ci} / \mathrm{g}$. The adsorption of these proteins to rumen bacteria was measured by adding $1 \mathrm{ml}$ of a solution of ${ }^{14} \mathrm{C}$-labelled protein to $5 \mathrm{ml}$ of chilled $\left(0^{\circ}\right)$ rumen bacteria, incubating at $0^{\circ}$ for $10 \mathrm{~min}$ and centrifuging this mixture at $27200 \mathrm{~g}$ for $15 \mathrm{~min}$ at $4^{\circ}$. The extent of adsorption of ${ }^{14} \mathrm{C}$-labelled protein was estimated from the differences in counts between the whole mixture and the supernatant fluid. Trichloroacetic acid-soluble radioactivity was estimated in a similar manner, by adding trichloroacetic acid (TCA) to incubation mixtures at a final concentration of $50 \mathrm{~g} / \mathrm{l}$, followed by centrifugation and counting by liquid-scintillation spectrometry. The concentration of ${ }^{14} \mathrm{C}$-labelled protein in the added solution was $0.6 \mathrm{mg} / \mathrm{ml}$ unless otherwise stated, giving a final concentration of $0.1 \mathrm{mg} / \mathrm{ml}$. The bacterial fraction from rumen fluid was used without further treatment in the experiments summarized in Fig. 1 (p. 402) and Table 1 (p. 403), which deal with the effects of the cell-free supernatant fluid as well as the bacteria, and other adsorption experiments were done with rumen bacteria which had been centrifuged and resuspended in $0.4 \mathrm{vol} .30 \mathrm{~mm}$-potassium phosphate, $\mathrm{pH} 7.5$.

The adsorption of enzymes to rumen bacteria was carried out in a similar way, except that the adsorption and subsequent desorption of protein was assessed by enzyme activity rather than radioactivity. Enzymes were adsorbed to resuspended rumen bacteria $(5 \mathrm{ml})$ by addition of a protein solution $(1 \mathrm{ml})$ containing $0.03 \mathrm{mg}$ glucose- 6 -phosphate dehydrogenase ( $E C$ I . I I . 49), $0.04 \mathrm{mg}$ glucosephosphate isomerase (EC 5.3 . I .9), $0.14 \mathrm{mg}$ hexokinase (EC 2.7.I. I) and $0.77 \mathrm{mg}$ haemoglobin. Following incubation at $0^{\circ}$ for $10 \mathrm{~min}$ and centrifugation, the pellet was resuspended in $6 \mathrm{ml}$ ice-cold $25 \mathrm{~mm}$-potassium phosphate, $\mathrm{pH} 7.5$, with or without added casein $(1 \mathrm{~g} / \mathrm{l})$, incubated for a further $10 \mathrm{~min}$ at $0^{\circ}$ and centrifuged. Enzyme activities were measured in the supernatant fractions from both centrifugations, using a double-beam recording spectrophotometer (CE595; Cecil Instruments, Cambridge), by the rate of increase in absorbance at $340 \mathrm{~nm}$ of a reaction mixture (pH 7.5 at $25^{\circ}$ ) containing $25 \mathrm{~mm}$-potassium phosphate and $0.2 \mathrm{~mm}$-NADP with the following additions: for glucose-6-phosphate dehydrogenase, $0.625 \mathrm{~mm}$-glucose-6-phosphate; for glucosephosphate isomerase, $0.625 \mathrm{~mm}$-fructose-6-phosphate and $15 \mu \mathrm{g}$ glucose6-phosphate dehydrogenase $/ \mathrm{ml}$; and for hexokinase, $0.625 \mathrm{~mm}$-glucose, $0.625 \mathrm{mM}$-ATP and $15 \mu \mathrm{g}$ glucose- 6 -phosphate dehydrogenase $/ \mathrm{ml}$. The volume of sample used in each assay $(1 \mathrm{ml})$ was $0.125 \mathrm{ml}$, with a tenfold dilution being used for the measurement of enzyme activity in the first supernatant fraction.

\section{Measurement of proteolytic activity}

Proteolytic activity was measured with ${ }^{14} \mathrm{C}$-labelled proteins in the same assay mixture as used for adsorption experiments except that the bacterial fraction was diluted tenfold in buffer. The mixture was incubated at $39^{\circ}$ for $30 \mathrm{~min}$, then TCA was added to a final concentration of $50 \mathrm{~g} / 1$. TCA-insoluble material was removed by centrifugation $(12000 \mathrm{~g}$, $3 \mathrm{~min}$ ) and a portion of the supernatant fluid was counted by liquid-scintillation spectrometry. Quenching in the sample was compensated for automatically from the spectral distribution of an external standard (Packard Tri-Carb 460CD Liquid Scintillation System). 
Arylamidase (EC 3.4.11.2) activity was measured using the substrates leucine $p$ nitroanilide and benzoyl arginine $p$-nitroanilide. These compounds were incubated at $39^{\circ}$ in an assay mixture $(\mathrm{pH} 7.5)$ containing $(/ \mathrm{ml}): 0.5 \mu \mathrm{mol}$ substrate, $25 \mu \mathrm{mol}$ potassium phosphate, $0.18 \mathrm{ml}$ bacterial fraction and $0.1 \mathrm{ml}$ ethanol. The reaction was terminated by adding an equal volume of $0.4 \mathrm{M}$-hydrochloric acid and the mixture was centrifuged at $12000 \mathrm{~g}$ for $3 \mathrm{~min}$. Supernatant fraction $(1 \mathrm{ml})$ was added to $2 \mathrm{ml} \mathrm{lM}$-sodium carbonate and the absorbance of this solution was measured at $405 \mathrm{~nm}$.

\section{Estimation of protein}

The protein content of bacterial suspensions was measured using the Folin reagent by the method of Herbert et al. (1971), using bovine serum albumin as standard.

\section{Chemicals}

$\left[{ }^{14} \mathrm{C}\right]$ Formaldehyde used to label proteins was obtained from Amersham International plc, Amersham, Bucks. Glucose-6-phosphate dehydrogenase from Leuconostoc mesenteroides, glucosephosphate isomerase (type III) from yeast, and other fine chemicals were obtained from Sigma Chemical Co. Ltd, Poole, Dorset. Yeast hexokinase was obtained from the Boehringer Corporation (London) Ltd, Lewes, Sussex.

\section{RESULTS}

\section{Adsorption of ${ }^{14} \mathrm{C}$-labelled casein to rumen bacteria}

Casein labelled by reductive methylation with $\left[{ }^{14} \mathrm{C}\right]$ formaldehyde (Wallace, 1983) was added to suspensions of rumen bacteria incubated at either $39^{\circ}$ or $0^{\circ}$ and containing a total protein concentration of either $1.77 \mathrm{mg} / \mathrm{ml}$ (comprising $0.1 \mathrm{mg}{ }^{14} \mathrm{C}$-labelled casein and $1.67 \mathrm{mg}$ unlabelled casein per $\mathrm{ml})$ or $0.1 \mathrm{mg} / \mathrm{ml}\left({ }^{14} \mathrm{C}\right.$-labelled casein only). Samples were removed periodically for the determination of total radioactivity, followed by centrifugation to sediment the bacteria. A sample of the supernatant fraction was counted, TCA was added and the centrifugation was repeated, removing undegraded protein. A sample of the supernatant fraction from this centrifugation was counted to determine TCA-soluble radioactivity.

At $39^{\circ}$ and $1.77 \mathrm{mg}$ protein $/ \mathrm{ml}$ (Fig. $1($ a)), radioactivity was progressively converted to a TCA-soluble form in the extracellular medium, leading to $>90 \%$ hydrolysis after $90 \mathrm{~min}$. When the initial concentration of protein was decreased to $0.1 \mathrm{mg} / \mathrm{ml}$, a number of differences were observed during the $39^{\circ}$ incubation (Fig. $1(b)$ ). More than half the counts were TCA-soluble at $5 \mathrm{~min}$, and all the extracellular counts were TCA-soluble after this time. However, this extracellular ${ }^{14} \mathrm{C}$ represented only about half the total radioactivity present in the suspension. When bacteria were disrupted by adding TCA to the whole suspension after 90 min incubation, all the ${ }^{14} \mathrm{C}$ was rendered TCA-soluble, indicating that the missing radioactivity was intracellular and of low molecular weight.

Incubation of these suspensions at $0^{\circ}$ effectively prevented proteolysis (Fig. 1(c,d)). At the high-casein concentration, the radioactivity found in the extracellular medium corresponded well with the total ${ }^{14} \mathrm{C}$ present (Fig. $1(c)$ ). In contrast, at the low-protein concentration (Fig. 1 $(d)$ ), there was a discrepancy between the total radioactivity and that found initially in the extracellular medium. This indicated that a small amount of intact ${ }^{14} \mathrm{C}$-labelled casein, which was an insignificant proportion of the total casein at the higher concentration, had adsorbed to rumen bacteria and sedimented with the bacteria. It was evident that at this low-casein concentration, TCA was ineffective in precipitating a large proportion of the protein present.

Removal of bacteria from the fluid prevented the sedimentation of undegraded ${ }^{14} \mathrm{C}$-labelled 


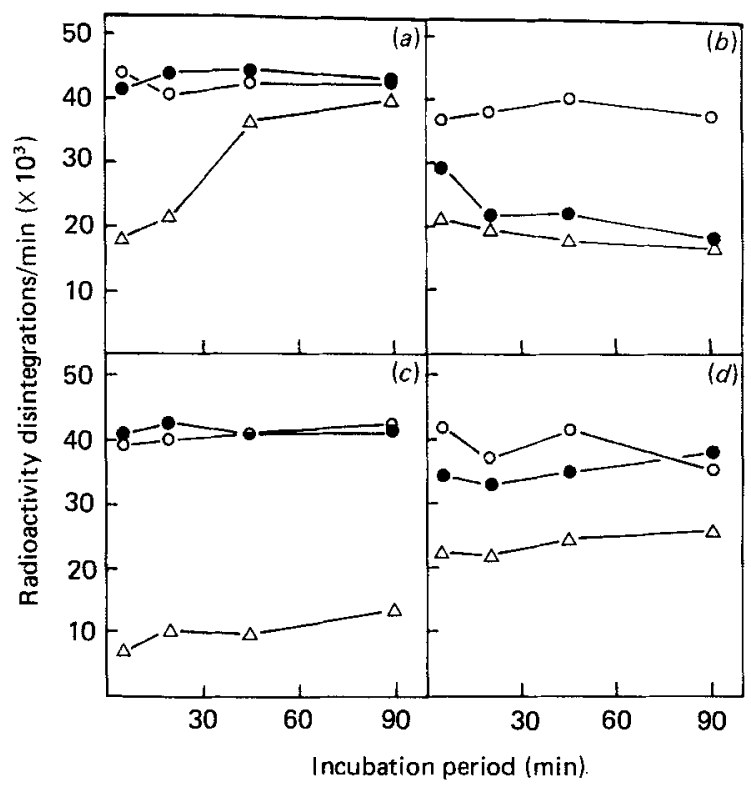

Fig. 1. Incubation of ${ }^{14} \mathrm{C}$-labelled casein with rumen bacteria. Rumen fluid from which protozoa had been removed by centrifugation was incubated with $0.1 \mathrm{mg}{ }^{14} \mathrm{C}$-labelled casein $(35 \mu \mathrm{Ci} / \mathrm{g}) / \mathrm{ml}:(a)$ with added $1.67 \mathrm{mg}$ unlabelled casein $/ \mathrm{ml}$ at $39^{\circ},(b)$ with no addition at $39^{\circ},(c)$ with added $1.67 \mathrm{mg}$ unlabelled casein $/ \mathrm{ml}$ at $0^{\circ}$ and $(d)$ with no addition at $0^{\circ}$. Radioactivity was counted in the total incubation mixture $(O)$, in the supernatant fluid following centrifugation $(12000 \mathrm{~g}, 3 \mathrm{~min})(\mathrm{O})$ and in the trichloroacetic acid-soluble fraction of the supernatant fluid $(\triangle)$.

casein, confirming that contact with bacteria was necessary for sedimentation to occur (Table 1). Furthermore, when rumen bacteria were boiled for $5 \mathrm{~min}$ before incubation with ${ }^{14} \mathrm{C}$-labelled casein at $0^{\circ}$, the sedimentation was abolished (Table 1), providing a possible indication of some specificity in the reaction. Removal of some capsular material by blending or shaking (Kopecny \& Wallace, 1982) had little $(<10 \%)$ influence on adsorption, and chemicals which similarly lacked effect when added to the incubation mixture included dithiothreitol (4 mM), cysteine (6 mM), methionine ( $6 \mathrm{mM})$, sodium chloride $(0.5 \mathrm{M})$, monensin $(1.7 \mu \mathrm{g} / \mathrm{ml})$, DEAE-cellulose $(16.7 \mathrm{mg} / \mathrm{ml})$ and linseed oil emulsion $(5 \mathrm{mg} / \mathrm{ml})$. Sodium stearate and trioctanoin at $1 \mathrm{mg} / \mathrm{ml}$ caused $25 \%$ inhibition of adsorption, and previous extraction of the cells with chloroform decreased adsorption by $37 \%$.

${ }^{14} \mathrm{C}$-Labelled casein was adsorbed to rumen bacteria, which were then washed, resuspended and subjected to several treatments to determine factors which would lead to the release of adsorbed protein (Table 2). Some material was released simply by resuspension, and all this was TCA-soluble. Similarly, the additional ${ }^{14} \mathrm{C}$ released by boiling or blending was mostly TCA-soluble. Only excess unlabelled casein or Triton X100 released TCA-insoluble material. Dithiothreitol had little effect.

The proportion of ${ }^{14} \mathrm{C}$-labelled casein adsorbed to rumen bacteria declined as its concentration was increased, consistent with the saturation of binding sites. A double reciprocal plot of the concentration of ${ }^{14} \mathrm{C}$-labelled casein added $v$. the amount of ${ }^{14} \mathrm{C}$-labelled casein adsorbed was linear. The concentration of ${ }^{14} \mathrm{C}$-labelled casein at half-saturation of adsorption sites was approximately $0.2 \mathrm{mg} / \mathrm{ml}$.

A small amount of undegraded ${ }^{14} \mathrm{C}$-labelled casein in the extracellular fluid was soluble in $50 \mathrm{~g} \mathrm{TCA} / 1$, and this amount was greatly increased when the rumen fluid had been boiled 
Table 1. Influence of boiling and removal of bacteria on the sedimentation of ${ }^{14} \mathrm{C}$-labelled casein from rumen fluid

$\left({ }^{14} \mathrm{C}\right.$-labelled casein was added to test solutions at $0^{\circ}$ and the proportion of radioactivity which was sedimented in the presence or absence of $50 \mathrm{~g} \mathrm{TCA} / \mathrm{l}$ was determined (pp. 401-402). The results are the means of duplicate estimations using a single sample of a bacterial fraction from sheep rumen fluid)

\begin{tabular}{lcc}
\hline \multicolumn{1}{c}{ Test solution } & $\begin{array}{c}\text { Percentage of }{ }^{4} \mathrm{C} \text {-labelled } \\
\text { casein sedimented }\end{array}$ \\
\cline { 2 - 3 } & No treatment & $50 \mathrm{~g} \mathrm{TCA} / 1$ \\
Bacterial fraction & $38 \cdot 2$ & $70 \cdot 2$ \\
Boiled $(5 \mathrm{~min})$ bacterial fraction & $3 \cdot 6$ & $29 \cdot 1$ \\
Supernatant fraction $(27200 \mathrm{~g})$ from bacterial fraction & $1 \cdot 5$ & $74 \cdot 1$ \\
Supernatant fraction $(27200 \mathrm{~g})$ from boiled bacterial fraction & $5 \cdot 2$ & $37 \cdot 0$ \\
\hline
\end{tabular}

TCA, trichloroacetic acid.

Table 2. Displacement of ${ }^{14} \mathrm{C}$-labelled casein adsorbed to bacteria prepared from sheep rumen fluid

(Mean values and standard deviations, $n 3$ )

\begin{tabular}{|c|c|c|c|c|}
\hline \multirow[b]{2}{*}{ Treatment } & \multicolumn{2}{|c|}{$\begin{array}{l}\text { Percentage of total } \\
{ }^{14} \mathrm{C} \text { displaced }\end{array}$} & \multicolumn{2}{|c|}{$\begin{array}{l}\text { Percentage of displaced } \\
{ }^{14} \mathrm{C} \text { soluble in } 50 \mathrm{~g} \text { TCA } / 1\end{array}$} \\
\hline & Mean & SD & Mean & SD \\
\hline None & 24 & 6 & 102 & 4 \\
\hline $5 \mathrm{~g}$ Triton $\mathrm{X} 100 / 1,0^{\circ}, 10 \mathrm{~min}$ & 45 & 7 & 54 & 7 \\
\hline $4 \mathrm{~mm}$-Dithiothreitol, $0^{\circ}, 10 \mathrm{~min}$ & 28 & 5 & 101 & 9 \\
\hline $1 \mathrm{~g}$ casein $/ 1,0^{\circ} 10 \mathrm{~min}$ & 40 & 2 & 47 & 7 \\
\hline $100^{\circ}, 5 \min$ & 72 & 4 & 97 & 2 \\
\hline Waring blender, $0^{\circ}, 5 \mathrm{~min}$ & 35 & 9 & 91 & 22 \\
\hline
\end{tabular}

TCA, trichloroacetic acid.

(Table 1). Although a full investigation of this phenomenon was not carried out, it was found that ${ }^{14} \mathrm{C}$-labelled lactoglobulin was similarly rendered TCA-soluble, that dithiothreitol ( $4 \mathrm{mM}$ ) and EDTA (15 mM) decreased the extent to which ${ }^{14} \mathrm{C}$-labelled casein was made TCA-soluble by 48 and $77 \%$ respectively, and that increasing the TCA concentration to $250 \mathrm{~g} / \mathrm{l}$ had no effect. Addition of $1 \mathrm{mg}$ casein $/ \mathrm{ml}$ in one experiment decreased the TCA solubility of $0.01 \mathrm{mg}{ }^{14} \mathrm{C}$-labelled casein $/ \mathrm{ml}$ from 50 to $8 \%$, indicating that saturation of the activity could occur. Treatment of boiled, clarified rumen fluid with $0.1 \mathrm{mg}$ pronase (EC $3.4 .24 .4) / \mathrm{ml}$ at $39^{\circ}$ for $30 \mathrm{~min}$, followed by boiling once more for $5 \mathrm{~min}$, had no effect on the extent of solubilization of ${ }^{14} \mathrm{C}$-labelled casein.

\section{Role of adsorption in proteolysis}

The part played by adsorption in the overall proteolytic mechanism was assessed by comparing the extent of adsorption and rate of hydrolysis of different pure proteins (Table 3) and the effects of inhibitors on hydrolysis and adsorption (Table 4).

At an initial protein concentration of $0.1 \mathrm{mg} / \mathrm{ml}$, casein was degraded most rapidly and $\gamma$-globulin and albumin most slowly of the five ${ }^{14} \mathrm{C}$-labelled proteins examined. The extent 
Table 3. Comparison of the rates of hydrolysis of different ${ }^{14} \mathrm{C}$-labelled proteins and their adsorption to rumen bacteria isolated from sheep rumen fluid

(Mean values and standard deviations, $n$ 6. The results are expressed relative to ${ }^{14} \mathrm{C}$-labelled casein $=100)$

\begin{tabular}{|c|c|c|c|c|}
\hline \multirow[b]{2}{*}{ Protein } & \multicolumn{2}{|c|}{ Hydrolysis } & \multicolumn{2}{|c|}{ Adsorption } \\
\hline & Mean & SD & Mean & SD \\
\hline Casein & 100 & - & 100 & -- \\
\hline Haemoglobin & 76 & $13 \cdot 3$ & 73 & $10 \cdot 1$ \\
\hline Lactoglobulin & 23 & 4.9 & 13 & 7.6 \\
\hline$\gamma$-Globulin & 10 & $9 \cdot 4$ & 5 & 8.6 \\
\hline Albumin & 10 & 8.9 & 8 & $3 \cdot 8$ \\
\hline
\end{tabular}

to which these proteins were adsorbed to the bacteria corresponded fairly closely to their initial rate of hydrolysis at this concentration (Table 3 ).

The influence of inhibitors on proteolysis and on adsorption of ${ }^{14} \mathrm{C}$-labelled casein followed a similar pattern (Table 4). $p$-Chloromercuribenzoate (PCMB), which reacts with sulphydryl groups, inhibited both by more than $60 \%$. Copper sulphate, the trypsin inhibitor $N \alpha$-p-tosyl-L-lysine chloromethylketone (TLCK) and the metalloprotease inhibitor 1,10phenanthroline inhibited both reactions by about half and EDTA had only a minor effect. The only possible exception was the serine protease inhibitor phenylmethylsulphonyl fluoride (PMSF), which apparently had less effect on adsorption than proteolysis. The effects of these inhibitors were investigated further using the synthetic aryl amides leucine $p$-nitroanilide (LNA) and benzoyl arginine $p$-nitroanilide (BANA), which are substrates for leucine aminopeptidase and trypsin-like activities respectively. Again, the extent to which different inhibitors influenced arylamidase activity was similar to the effects of these inhibitors on adsorption (Table 4). The only exception here was TLCK, which inhibited adsorption to a much greater extent than the hydrolysis of LNA.

\section{Reversibility of adsorption}

Nugent \& Mangan (1981) found that the adsorption of fraction I protein to rumen particles was essentially irreversible, as it could not be displaced and as only low-molecular-weight products were released. Here, ${ }^{14} \mathrm{C}$-labelled casein and haemoglobin were used to examine the reversibility of adsorption under different conditions (Table 5).

When bacteria, to which ${ }^{14} \mathrm{C}$-labelled casein had been adsorbed, were harvested and resuspended in buffer, then incubated at $39^{\circ}, 86 \%$ of the radioactivity was made TCA-soluble within $10 \mathrm{~min}$ (Table 5), presumably partly by hydrolysis of the ${ }^{14} \mathrm{C}$-labelled casein. At $0^{\circ}$, $61 \%$ of the counts were released into the medium and of these $97 \%$ were TCA-soluble. However, when the total protein concentration was increased by the addition of a tenfold excess of unlabelled casein, a considerable amount of TCA-insoluble radioactivity was released from the bacteria at both temperatures, indicative of high-molecular-weight peptides. A similar pattern was observed with ${ }^{14} \mathrm{C}$-labelled haemoglobin except that the rate of hydrolysis at $39^{\circ}$ was less rapid.

The adsorption of enzymes to rumen bacteria was carried out to determine if unmodified protein in the form of active enzyme could be recovered from rumen bacteria (Table 6). Three enzymes, glucose-6-phosphate dehydrogenase, glucosephosphate isomerase and hexokinase, were added to a bacterial suspension at $0^{\circ}$, incubated for $10 \mathrm{~min}$ at $0^{\circ}$ and centrifuged. Haemoglobin was added with the enzvmes to increase the total nrotein 


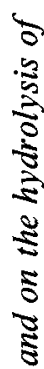

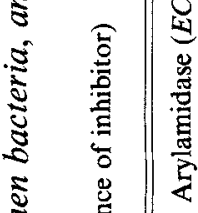

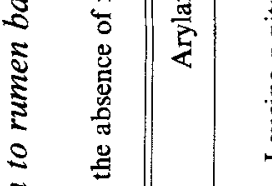

5.

\&

3

$\therefore$ 妾

$\$$

$5 \stackrel{\square}{\square}$

3

¿

i

守

Di

岕

के

స

ธิ

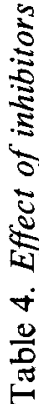

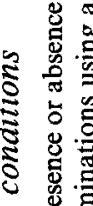

苛

守守宫
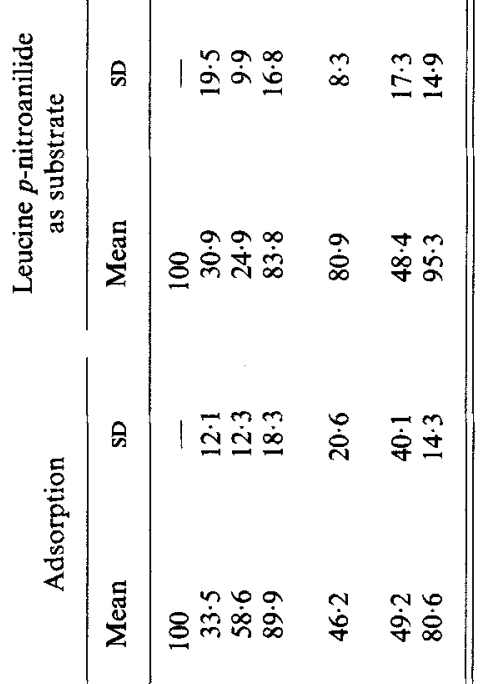

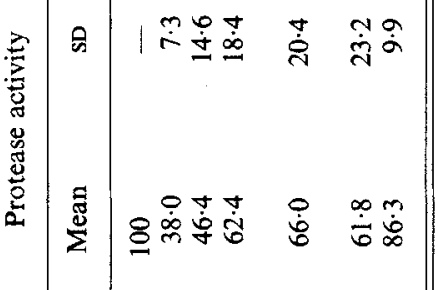

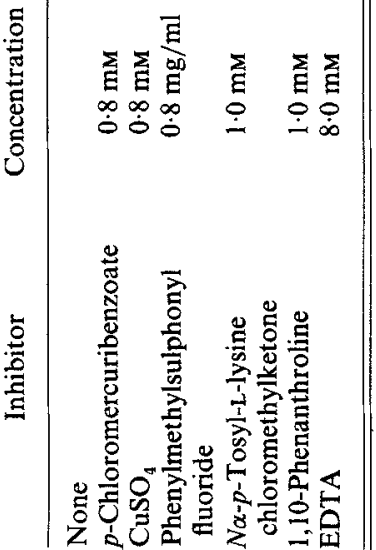

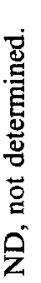

.

o

吾

$\equiv$ б

홍

:

密

\$용

. 5 के

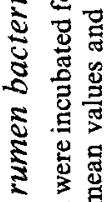

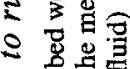

옹

吾要

응 홇

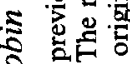

के

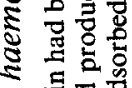

₹

艺 응

용 है:

U $\frac{\pi}{0}$

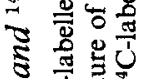

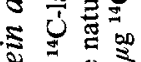

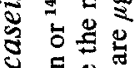

¿

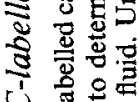

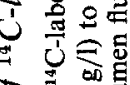

일

\&

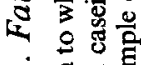

计哥

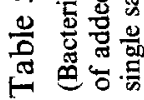

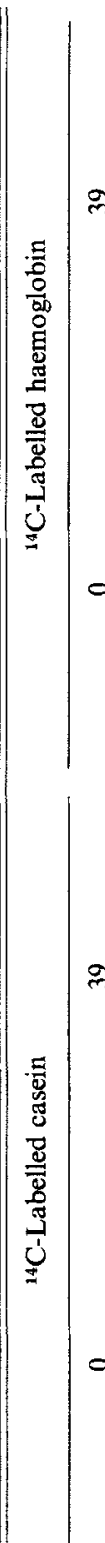

m

- 1 क

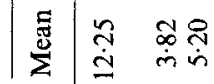

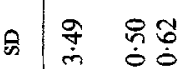

$\circ$

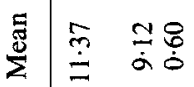

6 ¥ ํㅜㅇ

$-$

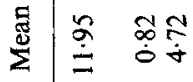

काㄷํㅇํㅇ

$\circ$

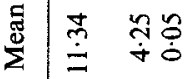

क F

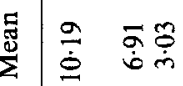

gे

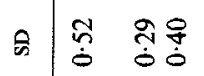

$\circ$

志

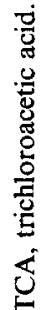

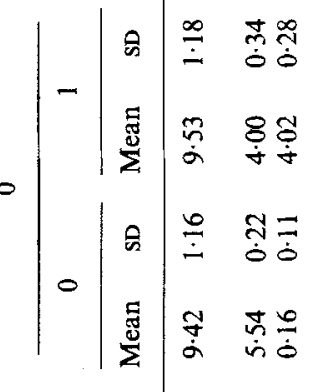

:

壱

。

焉

焉 $\vdots$ 离

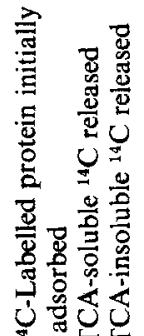


Table 6. Adsorption of enzymes to rumen bacteria prepared from sheep rumen fluid

(Enzymes were added to a suspension of rumen bacteria at $0^{\circ}$, which was then centrifuged and the pellet was resuspended in buffer or buffer and $1 \mathrm{mg}$ casein $/ \mathrm{ml}$, see p. 404 for details. Enzyme activities are expressed as $\mu \mathrm{mol}$ substrate metabolized $/ \mathrm{min}$ at $25^{\circ}$. The results are the means of two estimations)

\begin{tabular}{lcc}
\hline & \multicolumn{2}{c}{ Enzyme activity } \\
\cline { 2 - 3 } & $\begin{array}{c}\text { Glucose-6-phosphate } \\
\text { dehydrogenase } \\
(E C \text { I . I I . . 49) }\end{array}$ & $\begin{array}{c}\text { Glucosephosphate } \\
\text { isomerase } \\
(E C \text { 5.3 I.9) }\end{array}$ \\
\hline Activity added & 4.98 & 11.05 \\
Activity in Ist supernatant fraction & 3.46 & $9 \cdot 15$ \\
Loss of activity & 1.52 & 1.90 \\
Activity released on resuspension & & 0.35 \\
In buffer & 0.25 & 0.55 \\
In buffer + casein & 0.25 & \\
\hline \hline
\end{tabular}

concentration. The bacteria were then resuspended in buffer containing $1 \mathrm{mg}$ casein $/ \mathrm{ml}$ which had displaced TCA-insoluble material from adsorbed ${ }^{14} \mathrm{C}$-labelled casein and ${ }^{14} \mathrm{C}$-labelled haemoglobin (Table 5). Casein did not displace any glucose-6-phosphate dehydrogenase activity from the cells, and only a small amount of glucosephosphate isomerase was released (Table 6), indicating that little unmodified enzyme could be released following adsorption to rumen bacteria, even at $0^{\circ}$. The small amount of activity released was probably derived from interstitial water trapped in the pellet. The basal enzyme activity in the extracellular medium was low $(0.2 \%)$ in comparison with that added for glucose6-phosphate dehydrogenase and glucosephosphate isomerase activities, but was tenfold higher than the added activity for hexokinase, which is the reason why this enzyme was not measured in the adsorption experiment.

\section{DISCUSSION}

The adsorption of a protein to rumen bacteria at low concentrations was first reported by Nugent \& Mangan (1981), who pointed out the possible significance of this step in protein degradation in the rumen. These authors used fraction I leaf protein isolated from lucerne grown in the presence of ${ }^{14} \mathrm{CO}_{2}$ to study the behaviour of this protein at concentrations where its chemical detection in rumen fluid becomes problematical. In the present paper, the labelling of several pure proteins with ${ }^{14} \mathrm{C}$ was accomplished instead by a reductive methylation procedure using $\left[{ }^{14} \mathrm{C}\right]$ formaldehyde (Wallace, 1983). This modification did not affect the susceptibility of proteins to hydrolysis by rumen bacteria, and it is assumed here that adsorption would be similarly unaffected.

It was found previously (Wallace, 1983) that none of the radioactivity from a protein labelled in this way could be incorporated into microbial protein following degradation of that protein by rumen micro-organisms. This presumably means that the modified amino acid (probably $\mathrm{N} \epsilon$-methyl lysine) is not a substrate for protein synthesis. The lack of incorporation of ${ }^{14} \mathrm{C}$-labelled products into rumen bacteria was confirmed here (Fig. 1), but it was found additionally that the radioactive products of hydrolysis were accumulated by the bacteria, a property only noticeable at low concentrations of radioactive protein (Fig. 1). As disruption of the cells by TCA released all of the counts in an acid-soluble form, it would appear that the rumen bacteria formed a large concentration gradient of the radioactive product across the cell membrane. The ${ }^{14} \mathrm{C}$-labelled amino acid product of 
reductive methylation may therefore remain a substrate for bacterial transport mechanisms, despite the fact that it cannot be incorporated into bacterial protein. Similar phenomena have been found with non-metabolizable substrates in many species of bacteria.

The initial uptake of ${ }^{14} \mathrm{C}$-labelled casein by rumen particulate matter (Fig. 1) was less pronounced than that for fraction I protein (Nugent \& Mangan, 1981), and was best seen by incubating the mixture at $0^{\circ}$, which prevents proteolysis but permits adsorption to occur (Fig. 1; Nugent \& Mangan, 1981). This adsorption was found to be a saturable process. As the average quantity of ${ }^{14} \mathrm{C}$-labelled casein adsorbed at a concentration of $0.1 \mathrm{mg} / \mathrm{ml}$ was $3.5 \mu \mathrm{g} / \mathrm{mg}$ bacterial protein, and the concentration of ${ }^{14} \mathrm{C}$-labelled casein at half-saturation was $0 \cdot 2 \mathrm{mg} / \mathrm{ml}$, the maximum capacity for adsorption of ${ }^{14} \mathrm{C}$-labelled casein can be estimated to be about $10 \mu \mathrm{g} / \mathrm{mg}$ bacterial protein, somewhat lower than that for fraction I protein. Adsorption was abolished by boiling the bacteria (Table 1), just as it had been totally inhibited by sodium dodecyl sulphate (Nugent \& Mangan, 1981). Blending of the bacteria, which releases capsular material without cell lysis and at the same time solubilizes proteolytic activity (Kopecny \& Wallace, 1982), also released some adsorbed ${ }^{14} \mathrm{C}$-labelled casein (Table 2).

These findings, the removal of adsorbed ${ }^{14} \mathrm{C}$-labelled casein by Triton X100 (Table 2), and the sensitivity of adsorption to $15 \mathrm{~mm}$-magnesium sulphate and 15 mM-EDTA (Nugent \& Mangan, 1981), suggested an ionic interaction between soluble protein and a heat-sensitive component of cell surface layers of rumen bacteria. The nature of this component was not known, although the presence within these layers of the main proteolytic enzymes of rumen bacteria (Kopecny \& Wallace, 1982) suggested that the sites of adsorption and proteolysis might be the same.

The relation between protein adsorption and hydrolysis was further investigated by comparing the adsorption and rate of hydrolysis of different soluble proteins (Table 3 ) and the sensitivity of the two processes to inhibition (Table 4). Both of these criteria indicated that proteolysis and the adsorption of a protein to bacteria were intimately linked, but it was not clear if the rate-limiting process was the adsorption of the substrate to a site which then permitted proteolysis or if adsorption was likely to be directly to the proteolytic site itself. When the catalytic activity as measured by arylamidase $\left(E C C_{3}\right.$.4 I I .2) activity was found to be sensitive to inhibition in the same way as adsorption and proteolysis (Table 4), the latter interaction was concluded to be the correct one.

Different soluble proteins had quite different rates of hydrolysis (Table 3), as found previously (Mangan, 1972; Wallace \& Kopecny, 1983; Nugent et al. 1983; Wallace, 1983), confirming that protein structure as well as its solubility is an important determinant of its susceptibility to degradation. Here, at a protein concentration of $0.1 \mathrm{mg} / \mathrm{ml}$, the ranking order was slightly different from that found previously when the protein concentration was $2 \mathrm{mg} / \mathrm{ml}$ (Wallace, 1983). In particular, lactoglobulin was relatively much more slowly hydrolysed. This was due to its unusually high $K_{m}$ (Michaelis-Menten constant) for hydrolysis. The experiments with inhibitors and synthetic substrates were consistent with those using extracted bacterial proteases (Kopecny \& Wallace, 1982; Wallace \& Kopecny, 1983) and whole bacteria (Brock et al. 1982), which showed that the proteases of rumen bacteria are mainly cysteine proteases, with some serine and metalloprotease activity as well, and that they have specificities principally of the trypsin and leucine aminopeptidase types. This sensitivity of protease activity to inhibitors is more similar to that found with Bacteroides ruminicola (Hazlewood \& Edwards, 1981) than to that of Bacteroides amylophilus (Blackburn, 1968). However, no significant adsorption of ${ }^{14} \mathrm{C}$-labelled casein has been found with proteolytic cultures of B. ruminicola $(\mathrm{R}$. J. Wallace and M. L. Brammall, unpublished results).

Another property which suggested that adsorption and hydrolysis sites might be identical 
was that only low-molecular-weight products were released from fraction I protein once it had adsorbed to rumen bacteria (Nugent \& Mangan, 1981). In the present work (Table 5), no acid-insoluble, high-molecular-weight products were released from adsorbed ${ }^{14} \mathrm{C}$-labelled casein or ${ }^{14} \mathrm{C}$-labelled haemoglobin when cells to which they were adsorbed were resuspended in buffer, but such products were found to be displaced on the addition of a higher concentration of unlabelled casein. Thus adsorption appeared to be potentially reversible. However, when the experiment was repeated using enzymes as the adsorbed proteins, little if any enzyme activity was displaced by $1 \mathrm{mg}$ casein $/ \mathrm{ml}$ (Table 6). It is therefore likely that even the high-molecular-weight material displaced by casein (Table 5) had been partly hydrolysed. The finding that $42 \%$ of the ${ }^{14} \mathrm{C}$-labelled casein displaced when excess unlabelled casein was added was TCA-soluble (Table 5) tended to confirm this view. Presumably some slight hydrolytic activity remains at $0^{\circ}$, but the products usually remain adsorbed to the bacteria and so do not appear in the extracellular fluid unless displaced by an excess of alternative substrate.

The interpretation of many of the experiments reported in the present paper was complicated by the discovery that the extracellular fluid of rumen contents enables small quantities of undegraded protein to remain soluble in $50 \mathrm{~g} \mathrm{TCA} / 1$ (Fig. 1, Table 5), a property only observable at the low-protein concentrations used in adsorption experiments. When rumen fluid was boiled, then centrifuged, the capacity of the extracellular fluid to maintain undegraded protein soluble in TCA was greatly increased (Table 1), suggesting that boiling released a factor from rumen bacteria which caused this curious phenomenon. Boiling rumen bacteria causes a marked increase in the protein content of the extracellular liquid (R. J. Wallace, unpublished results) but, as pronase treatment of cell-free fluid did not diminish the activity, it seems unlikely that a protein was responsible. Other polymers were probably released by this treatment as well, but at this stage it is not possible to identify the cause of the solubilization. However, when twenty laboratory strains of rumen bacteria were tested for analogous properties, only one isolate of Selenomonas ruminantium and another of Butyrivibrio fibrisolvens produced a similar effect (R. J. Wallace and M. L. Brammall, unpublished results).

In conclusion, the present experiments show that adsorption of soluble proteins to the surfaces of rumen bacteria is probably an integral part of the catalytic process rather than a separate phenomenon. Manipulation of adsorption may therefore not be separable from manipulation of proteolysis itself, as was first hoped. It remains to be seen if colonization of insoluble protein supplements by proteolytic rumen bacteria depends on the same or a different mechanism.

The skilled technical assistance of Margaret L. Brammall is gratefully acknowledged.

\section{REFERENCES}

Blackburn, T. H. (1968). Journal of General Microbiology 53, 37-51.

Blackburn, T. H. \& Hobson, P. N. (1960). Journal of General Microbiology 22, 272-281.

Brock, F. M., Forsberg, C. W. \& Buchanan-Smith, J. G. (1982). Applied and Environmental Microbiology 44, $561-569$.

Hazlewood, G. P. \& Edwards, R. (1981). Journal of General Microbiology 125, 11-15.

Herbert, D., Phipps, P. J. \& Strange, R. E. (1971). Methods in Microbiology 5B, $209-344$.

Kopecny, J. \& Wallace, R. J. (1982). Applied and Environmental Microbiology 43, 1026-1033.

Mangan, J. L. (1972). British Journal of Nutrition 27, 261-283.

Nugent, J. H. A., Jones, W. T., Jordan, D. J. \& Mangan, J. L. (1983). British Journal of Nutrition 50, $357-368$.

Nugent, J. H. A. \& Mangan, J. L. (1981). British Journal of Nutrition 46, 39-59.

Wallace, R. J. (1983). British Journal of Nutrition 50, 345-355.

Wallace, R. J. \& Kopecny, J. (1983). Applied and Environmental Microbiology 45, 212-217.

Wright, D. E. (1967). Applied Microbiology 15, 547-550. 